\title{
HUBUNGAN INTERPESONAL SKILLS DENGAN KINERJA BIDAN DALAM PELAYANAN ANTENAAL CARE (ANC) DI KOTA PEKANBARU TAHUN 2017
}

\author{
Vivi Juwitasari ${ }^{1}$, Rully Hevrialni ${ }^{2}$, Junaida Rahmi ${ }^{2}$ \\ * Jurusan Kebidanan Poltekkes Kemenkes Riau
}

\begin{abstract}
ABSTRAK
Pelayanan kebidanan yang berkualitas sangat dipengaruhi oleh kompetensi bidan dalam memberikan pelayanan kebidanan. Kompetensi bidan yang harus dimiliki tidak saja hard skill tetapi juga soft skill agar dapat dikatakan sebagai bidan yang profesional. Dalam memberikan asuhan kebidanan seorang bidan idealnya memiliki kompetensi interpersonal skills yang baik, agar terjalin hubungan yang baik antara bidan dan pasien, bidan dan keluarga pasien serta bidan dan teman sejawat. Interpersonal skills merupakan kemampuan untuk memahami orang lain, apa yang memotivasi orang lain, bagaimana mereka bekerja, bagaimana kerjasama yang mereka lakukan. Penelitian ini bertujuan untuk mengetahui hubungan interpersonal skills dengan kinerja bidan dalam pelayanan ANC. Jenis penelitian ini adalah deskriptif analitik dengan desain cross sectional. Penelitian ini dilaksanakan bulan September 2016 - Juni 2017. Populasi pada penelitian ini adalah seluruh BPM di Kota Pekanbaru Tahun 2017. Sedangkan sampelnya adalah 59 BPM yang sesuai dengan kriteria inklusi. Teknik sampling yang digunakan adalah purposive sampling. Instrumen penelitian menggunakan lembar observasi dan lembar checklist. Analisa data menggunakan uji Chi Square. Hasil penelitian menunjukkan bahwa sebagian besar responden berumur 40-44 tahun sebanyak $(23,7 \%)$, berpendidikan DIII sebanyak $(71,2 \%)$, masa bekerja $\geq 3$ tahunsebanyak (96,6\%), bukan bidan delima sebanyak $(67,7 \%)$ dan asal institusi swasta sebanyak $(55,9 \%)$. Sebagian besar interpersonal skills responden adalah interpersonal skills baik yaitu sebesar (61\%). Sebagian besar kinerja bidan dalam pelayanan ANC responden adalah baik yaitu sebesar $(67,8 \%)$. Terdapat hubungan yang bermakna antara hubungan interpersonal skills dengan kinerja bidan dalam pelayanan ANC $(\mathrm{p}=0,00)$. Disarankan bagi IBI agar dapat mengupdate pengetahuan dan skill bidan tentang interpersonal skills khususnya dalam memberikan pelayanan ANC misalnya melalui seminar, workshop dan pelatihan.
\end{abstract}

\section{Kata kunci : Interpersonal skills, Kinerja Bidan dalam Pelayanan Antenatal Care (ANC)}

Daftar Pustaka : 39 (2002-2015) PENDAHULUAN

Tingginya Angka Kematian Ibu (AKI) salah satunya ditenggarai karena kualitas pelayanan kebidanan yang belum memadai baik dari tenaga kesehatan, peralatan kesehatan, dan transportasi kesehatan yang memperbesar risiko kematian ibu (Depkes RI, 2006).

Tercatat AKI di Provinsi Riau pada tahun 2014 adalah 124,5 per 100.000 kelahiran hidup. Gambaran kematian ibu dari angka tersebut menunjukkan bahwa walaupun akses pelayanan kesehatan mengalami peningkatan dalam 5 tahun terakhir, namun hal tersebut tidak diikuti dengan penurunan kematian ibu yang signifikan. Selain itu, peningkatan jumlah tenaga kesehatan dalam hal ini bidan di Provinsi Riau tercatat baik, namun juga tidak mempengaruhi menurunnya kematian 
ibu di Provinsi Riau (Dinas Kesehatan Riau, 2014).

Pelayanan kebidanan yang berkualitas sangat dipengaruhi oleh kompetensi bidan dalam memberikan pelayanan kebidanan. Kompetensi yang harus dimiliki oleh seorang bidan meliputi sejak kehamilan, persalinan, masa nifas, bayi baru lahir, keluarga berencana, pada bayi dan balita, dan pada ibu atau wanita dengan gangguan reproduksi. Berdasarkan Kepmenkes RI No: 369/Menkes/SK/III/2007, seorang bidan dalam menerapkan asuhan kebidanan harus sesuai standar profesi. Dengan demikian bidan harus memiliki kompetensi tidak saja hard skill tetapi juga soft skill agar dapat dikatakan sebagai bidan yang profesional (Kemenkes,2007).

Soft skill terdiri dari dua komponen yaitu intrapersonal skill dan interpersonal skill.Interpersonal skill adalah keterampilan seseorang yang diperlukan dalam berhubungan dengan orang lain. Menurut teori Patrick S. O'Brien, terdapat tujuh area yang disebut dengan winning characterictics (karakter pemenang) yaitu communication skill, organization skill, leadership, logic, effort, group skill, dan ethics, dalam hal ini seseorang yang beretika dalam sikap dan perilakunya akan disebut sebagai pemenang sebab orang yang demikian akan mampu mendapatkan kepercayaan dari orang lain (Ma'Arif, 2008).

Dengan interpersonal skills bidan diharapkan dapat menjalin dan menanamkan image positif seperti memberikan pelayanan kesehatan sesuai dengan kebutuhan dan keinginan pasien. Hal ini akan berdampak terhadap hubungan yang baik dengan seseorang, baik hubungan atau kontak dengan pasien, keluarga pasien, dan teman sejawat atau profesi (Aini, 2013).

$\begin{array}{rrr}\text { Memberikan asuhan } & \text { kebidanan } \\ \text { seorang bidan idealnya memiliki }\end{array}$ kompetensi interpersonal skills yang baik, agar terjalinnya hubungan yang baik antara bidan dan pasien, bidan dan keluarga pasien serta bidan dan teman sejawat. Selain itu bidan menjalani tugas fungsi bidan harus memiliki kemampuan berorganisasi dengan baik karena bidan harus dapat memimpin orang lain dengan komunikasi yang baik, serta mampu untuk bekerja sama dengan orang lain dalam satu grup untuk memiliki kemampuan yang solid (Ma'Arif, 2008).

Komunikasi merupakan alat membangun hubungan terapeutik yang mempengaruhi proses asuhan, mempengaruhi tingkah laku pasien dan kemudian untuk mendapatkan keberhasilan dalam intervensi asuhan. Menurut penelitian Hanafi (2012) terdapat pengaruh keterampilan knmunikasi interpersonal skill deng enaga kesehatan dalam peningkataı кеpuasan pasien.

Tenaga kesehatan khususnya bidan diharapkan mampu untuk memberikan pelayanan yang berkualitas dan sesuai standar. Hal ini dikarenakan dari tahun ke tahun permintaan masyarakat terhadap peran aktif bidan dalam memberikan pelayanan terus meningkat dan juga menjadi bukti bahwa eksistensi bidan ditengah masyarakat semakin memperoleh kepercayaan, pengakuan dan penghargaan. Dalam hal ini, bidan dituntut untuk terus meningkatkan kemampuan sekaligus mempertahankan dan meningkatkan kualitas pelayanannya termasuk pelayanan antenatal care (ANC). Pelayanan ANC harus dilakukan secara rutin, sesuai standar dan terpadu untuk pelayanan ANC yang berkualitas (Kemenkes, 2010).

Berdasarkan survey pendaluhuan di beberapa Puskesmas Kota Pekanbaru masih banyak bidan yang memberikan pelayanan ANC dengan standar 10T. Kementerian kesehatan telah membuat program standar pemeriksaan kehamilan 
14T tahun 2014, namun dalam pelaksanaannya dibeberapa Puskesmas Kota Pekanbaru dan BPM masih menggunakan standar pelayanan pemeriksaan kehamilan 10T. Dari 6 bidan praktik mandiri $83 \%$ masih memberikan pelayanan ANC terstandar 10T dikarenakan kurangnya pengawasan dari organisasi profesi dan pada standar 14T banyak pemeriksaan yang mengharuskan bidan untuk bekerja sama dengan tenaga medis lain seperti tenaga medis laboratorium maka dari itu bidan mengalami kendala dalam memberikana pelayanan ANC terstandar 14T. Dari ke 6 bidan mengatakan bahwa dari 10T tersebut yang jarang dilakukan pemeriksaannya adalah tes laboratorium, dikarenakan perlunya kolaborasi dengan tenaga medis laboratorium.

Berdasarkan data Pengurus Cabang IBI Kota Pekanbaru pada tahun 2015 terdapat 227 Bidan Praktik Mandiri. Survei awal yang dilakukan pada pasien di 6 orang bidan praktik mandiri ditemukan bahwa $80 \%$ pasien mengatakan bahwa bidan memiliki kemampuan interpersonal skill yang kurang baik, yaitu tentang informasi yang kurang jelas tentang kesehatan, kompetensi bidan yang kurang terampil, kelalaian atau kecerobohan dalam memberikan pelayanan, komunikasi efektif antara bidan dan pasien yang kurang terbangun.

Penelitian ini dilaksanakan untuk mengetahui hubungan interpersonal skills dengan kinerja bidan dalam pelayanan antenatal care (ANC) di Kota Pekanbaru tahun 2017.

\section{METODE PENELITIAN}

Jenis penelitian ini adalah penelitian deskriptif analitik dengan desain penelitian cross sectional. Teknik pengumpulan data menggunakan data primer yang dikumpulkan melalui observasi dengan lembar checklist dan kuesioner. Populasi penelitian ini adalah seluruh Bidan Praktik Mandiri di Kota Pekanbaru. Penelitian dilakukan pada bulan September 2016 sampai Juli 2017. Pengampilan sampel dalam penelitian ini dengan menggunakan purporsive sampling dengan jumlah sampel 59 orang. Analisis data dilakukan secara univariat dan bivariat dengan pengolahan data menggunakan SPSS dengan uji statistik Chi Square.

\section{HASIL PENELITIAN}

\section{Analisa Univariat}

Tabel 1. Distribusi Responden Berdasarkan Karakteristik Bidan di Kota Pekanbaru tahun 2017

\begin{tabular}{|c|c|c|c|}
\hline No & Karakteristik & $\begin{array}{l}\text { Jumlah } \\
(\mathrm{N})\end{array}$ & $\begin{array}{c}\text { Persentase } \\
(\%)\end{array}$ \\
\hline \multirow[t]{10}{*}{1.} & Umur & & \\
\hline & a. $25-29$ & 4 & 6.8 \\
\hline & b. $30-34$ & 5 & 8.5 \\
\hline & c. $35-39$ & 4 & 6.8 \\
\hline & d. $40-44$ & 14 & 23.7 \\
\hline & e. $45-49$ & 12 & 20.3 \\
\hline & f. $50-54$ & 7 & 11.9 \\
\hline & g. $55-59$ & 5 & 8.5 \\
\hline & h. $60-64$ & 8 & 13.6 \\
\hline & Jumlah & 59 & 100 \\
\hline \multirow[t]{4}{*}{2.} & Pendidikan & & \\
\hline & a. DIII & 42 & 71,2 \\
\hline & b. DIV & 17 & 28,8 \\
\hline & Jumlah & 59 & 100 \\
\hline \multirow[t]{5}{*}{3.} & Lama Bekerja & & \\
\hline & a. Baru $\quad(<3$ & 2 & 3,4 \\
\hline & tahun) & 57 & 96,6 \\
\hline & $\begin{array}{l}\text { b. Lama } \\
\text { ( } \geq 3 \text { tahun) }\end{array}$ & & \\
\hline & Jumlah & 59 & 100 \\
\hline \multirow[t]{8}{*}{4.} & Bidan & & \\
\hline & Delima/bukan & 40 & 67,7 \\
\hline & a. Bukan & 19 & 32,2 \\
\hline & Bidan & & \\
\hline & Delima & & \\
\hline & b. Bidan & & \\
\hline & Delima & & \\
\hline & Jumlah & 59 & 100 \\
\hline \multirow[t]{5}{*}{5.} & Institusi & & \\
\hline & Pendidikan & 33 & 55,9 \\
\hline & a. Swasta & 26 & 44,1 \\
\hline & b. Negeri & & \\
\hline & Jumlah & 59 & 100 \\
\hline
\end{tabular}


Tabel 2. Distribusi Responden Berdasarkan Kategori Interpersonal Skills Bidan Di Kota Pekanbaru tahun 2017

\begin{tabular}{llcc}
\hline No & $\begin{array}{l}\text { Kategori } \\
\text { Interpersonal } \\
\text { Skils }\end{array}$ & Jumlah & $\begin{array}{c}\text { Persentase } \\
(\%)\end{array}$ \\
\hline 1 & Baik & 36 & 61 \\
2 & Cukup & 23 & 39 \\
\hline & Jumlah & 59 & 100 \\
\hline
\end{tabular}

Tabel 3. Distribusi Responden Berdasarkan Kategori Pelayanan Antenatal Care (ANC) Bidan Di Kota Pekanbaru tahun 2017

\begin{tabular}{clcc}
\hline No & $\begin{array}{l}\text { Kategori } \\
\text { Pelayanan } \\
\text { Antenatal Care } \\
\text { (ANC) }\end{array}$ & Jumlah & $\begin{array}{c}\text { Persentase } \\
(\%)\end{array}$ \\
\hline 1 & Baik & 40 & 67,8 \\
2 & Cukup & 19 & 32,3 \\
\hline & Jumlah & 59 & 100 \\
\hline
\end{tabular}

2. Analisa Bivariat

Tabel 4. Hubungan Interpersonal Skills Dengan Kinerja Bidan Dalam Pelayanan Antenatal Care (ANC) Di Kota Pekanbaru Tahun 2017

\begin{tabular}{lccccccc}
\hline $\begin{array}{l}\text { Inter- } \\
\text { personal } \\
\text { Skills }\end{array}$ & \multicolumn{9}{c}{ Antenatal Care (ANC) } & Total & $\begin{array}{c}\text { Nilai } \\
\mathrm{p}\end{array}$ \\
\cline { 2 - 8 } & \multicolumn{2}{c}{ Baik } & \multicolumn{2}{c}{ Cukup } & & & \\
\cline { 2 - 8 } & $\mathrm{N}$ & $\%$ & $\mathrm{~N}$ & $\%$ & $\mathrm{~N}$ & $\%$ & \\
\hline Baik & 31 & 52,5 & 5 & 8,5 & 36 & 100 & \\
Cukup & 9 & 15,3 & 14 & 23,7 & 23 & 100 & 0,00 \\
\hline Total & 40 & 67,8 & 19 & 32,2 & 59 & 100 & \\
\hline
\end{tabular}

\section{PEMBAHASAN}

Menurut peneliti interpersonal skills yang baik pada seorang bidan tentu akan menghasilkan kinerja bidan yang baik dalam memberikan pelayanan ANC karena interpersonal skills ini mampu untuk memahami dan memotivasi pasien, sehingga bidan dapat memahami kebutuhan pasien saat memberikan pelayanan ANC yang berdampak pada kepuasan pasien. Sesuai dengan hasil penelitian yang dilakukan oleh Hanafi I (2012) yang menunjukkan hasil bahwa interpersonal skills yang baik dapat meningkatkan kepuasan pasien baik melalui kemampuan komunikasi, keterampilan bekerja serta etika saat memberikan pelayanan.Namun dalam penelitian ini masih dijumpai $8,5 \%$ bidan dengan interpersonal skills yang baik tetapi kinerja pelayanan ANC cukup. Hal ini dikarenakan bidan tersebut menguasai secara teori dan konsep namun tidak menerapkan kedalam pelayanan kebidanan yang diberikan, khususnya pelayanan ANC misalnya pemeriksaan laboratorium, perhitungan DJJ, dan pemeriksaan tekanan darah.

Untuk kategori interpersonal skills bidan dalam pelayanan ANC dinilai melalui observasi menggunakan kuesioner yang berupa pernyataan-pernyataan yang berhubungan dengan interpersonal skills meliputi kemampuan komunikasi, keterampilan organisasi, kepemimpinan, logika, upaya kemampuan bekerja, keterampilan kelompok, dan etika bekerja. Berdasarkan hasil observasi tidak seluruh item dalam komponen interpersonal skills dilakukan dengan baik yaitu keterampilan organisasi, keterampilan kelompok dan logika. Namun terdapat beberapa item dalam komponen interpersonal skills yang dilakukan dengan baik yaitu kemampuan komunikasi, kepemimpinan dan etika bekerja.

Hal ini dikarenakan komponen tersebut merupakan modal utama bagi seorang bidan dalam memberikan pelayanan terutama dalam memberikan pelayanan ANC. Dalam komponen kemampuan berkomunikasi sebagian besar bidan melakukan sesuai dengan item-item yang terdapat pada komponen tersebut seperti menyapa pasien dengan memanggil nama pasien dengan ramah, menjelaskan dengan bahasa yang sederhana dan mudah 
dipahami mengenai hasil pemeriksaan yang dilakukan, dan mendengarkan keluhan pasien dan memberikan penjelasan tentang tindakan, pengobatan yang akan diberikan secara jelas.

Dalam komponen kepemimpinan sebagian besar bidan melakukan sesuai dengan item-item yang terdapat pada komponen tersebut seperti mampu mengatur BPM nya, memberikan kesempatan kepada anggota tim untuk memberikan gagasan/ide, dan mampu memahami posisi dan kepentingan dalam sebuah konflik dan bisa menghasilkan solusi konflik yang dialami pasien. Sedangkan dalam komponen etika bekerja sebagian besar bidan melakukan sesuai dengan item-item yang terdapat pada komponen tersebut seperti menghormati martabat dan rahasia pasien, bersikap ramah saat berinteraksi dengan pasien, dan bersikap sopan santun saat berinteraksi dengan pasien. Dalam penelitian ini masih terdapat $15,3 \%$ bidan dengan kategori interpersonal skills yang cukup, namun kinerja pelayanan ANC baik. Hal ini dikarenakan kemampuan dalam berorganisasi dipengaruhi oleh kesamaan visi dan misi, jika terdapat perbedaan visi dan misi maka tidak akan tercapai tujuan organisasi sehingga keterampilan organisasi berkurang. Dalam penelitian ini sudah sebagian besar bidan/ BPM yang memiliki visi misi di BPMnya yaitu $60 \%$. Pada komponen logika dapat terlihat melalui cara bidan memberikan solusi terhadap masalah pasien, hal ini erat kaitannya dengan pengetahuan bidan. Bila pengetahuan bidan kurang maka bidan tidak dapat memberikan solusi terhadap masalah pasien sehingga mempengaruhi logika. Menurut Notoatmodjo (2012) pengetahuan yang baik dari seseorang akan memberikan kemampuan seseorang untuk dapat berfikir secara kritis dalam memecahkan suatu masalah untuk mendapatkan solusi dari masalah tersebut.
Dalam penelitian ini komponen yang masih kurang dipahami oleh bidan meliputi keterampilan organisasi, keterampilan kelompok, dan logika. Dalam komponen keterampilan sebagian besar bidan tidak melakukan sesuai dengan itemitem yang terdapat dalam komponen tersebut. Sementara diketahui komponen tersebut sangat mempengaruhi dalam memberikan pelayanan serta dapat mewujudkan prestasi kerja bidan sesuai dengan yang dikemukakan oleh Aini et al. (2015) yang menyebutkan bahwa keterampilan sangat menentukan hasil kinerja yang optimal, dimana keterampilan tersebut dapat diperoleh melalui pelatihan baik formal maupun non formal.

Berdasarkan hasil observasi dalam penelitian ini, tidak semua pemeriksaan yang terdapat dalam standar ANC 10T dilakukan oleh bidan. Selain itu terdapat juga beberapa pemeriksaan yang dilakukan bidan namun tidak sesuai dengan SOP pemeriksaan kehamilan. Namun tidak sedikit pemeriksaan yang dilakukan oleh bidan sesuai dengan SOP pemeriksaan kehamilan.

Saat memberikan pelayanan ANC, pemeriksaan yang paling banyak dilakukan dengan tepat oleh bidan yaitu palpasi abdomen, pemeriksaan LILA dan konseling. Hal ini dikarenakan item-item tersebut rutin dilakukan pada setiap pemeriksaan ANC. Selain itu, pemeriksaan tersebut juga mudah untuk dilakukan dan tidak membutuhkan kolaborasi dengan tenaga kesehatan lain. Dalam melakukan pemeriksaan abdomen, sebagian besar bidan sudah melakukan sesuai dengan SOP pemeriksaan ANC yaitu dengan menggunakan prasat Leopold. Begitu juga dengan pemeriksaan LILA. Untuk pemberian konseling, sebagian besar bidan sudah memberikan konseling sesuai dengan kebutuhan pasien dan tidak hanya sebatas gejala klinik saja (Pakage, 2014). 
Sedangkan pemeriksaan yang jarang dilakukan atau pun tidak tepat dilakukan oleh bidan yaitu pemeriksaan labor, pemeriksaan DJJ, pemeriksaan tekanan darah dan pemberian tablet Fe. Untuk pemeriksaan labor, terdapat beberapa bidan yang tidak melakukannya seperti pemeriksaan urin dan $\mathrm{Hb}$. Hal ini dikarenakan untuk melakukan pemeriksaan tersebut bidan harus memiliki kesediaan alat laboratorium yang memadai dan berkolaborasi dengan tenaga laboratorium, sedangkan berdasarkan Standar Pelayanan Kebidanan (SPK) pada ibu hamil minimal harus dilakukan rutin pemeriksaan labor melliputi pemeriksaan $\mathrm{Hb}$, glukosa dan protein urine. Namun, terdapat beberapa bidan yang berkolaborsi dengan pihak puskesmas dalam pemeriksaan labor tersebut sehingga pemeriksaan labor tetap dilakukan kepada pasien meskipun tidak di BPM. Hal ini sesuai dengan pendapat Ananta (2014) yang mengemukakan bahwa pemeriksaan laboratorium jarang dilakukan karena dipengaruhi oleh ketidak lengkapan fasilitas pemeriksaan.

Untuk pemeriksaan DJJ, sebagian besar bidan tidak melakukan penghitungan DJJ selama 1 menit, dan hanya dilakukan selama 15 detik. Hal ini terjadi karena sebagian besar bidan beralasan untuk meminimalkan waktu. Dalam pemeriksaan tekanan darah, sebagian besar bidan tidak melakukan palpasi nadi radialis dan brachialis terlebih dahulu. Sedangkan untuk pemberian tablet Fe, sebagian besar bidan tidak menjelaskan efek samping pengkonsumsian tablet $\mathrm{Fe}$ dan pada tidak memastikan kembali bahwa pasien mengkonsumsi 90 tablet $\mathrm{Fe}$ selama kehamilannya. Hal ini sesuai dengan hasil penelitian Hamidah, et al. (2014) yang mengemukakan bahwa sebesar 98,85\% bidan tidak menjelaskan cara dan efek samping pengkonsumsian tablet $\mathrm{Fe}$ dan tidak dilakukan evaluasi apakah pasien sudah mengkonsumsi 90 tablet Fe selama hamil, sebagian besar bidan hanya memberikan tablet Fe dan menganjurkan ibu agar mengkonsumsinya.

\section{KESIMPULAN}

Terdapat hubungan yang bermakna antara interpersonal skills dengan kinerja pelayanan antenatal care (ANC) ( $\mathrm{p}=$ $0,00)$.

\section{SARAN}

1. Bagi Tenaga Kesehatan

Diharapkan bagi tenaga kesehatan khususnya bidan agar dapat meningkatkan interpersonal skills dalam memberikan pelayanan antenatal care (ANC) yang sesuai dengan standar minimal antenatal care (ANC) 10T dan sesuai dengan SOP pemeriksaan kehamilan. Diharapkan bagi bidan yang memiliki interpersonal skills baik tetapi kinerja yang cukup untuk dapat meningkatkan kinerjanya dalam memberikan pelayanan antenatal care (ANC). Dan diharapkan juga bagi organisasi profesi (IBI) agar dapat mengupdate pengetahuan dan skill bidan tentang interpersonal skills khususnya dalam memberikan pelayanan antenatal care (ANC) misalnya melalui seminar, workshop dan pelatihan.

2. Bagi Peneliti Selanjutnya

Bagi peneliti selanjutnya dapat melanjutkan penelitian mengenai "Hubungan Interpersonal Skills dengan Kinerja Bidan Dalam Pelayanan Antenatal Care (ANC) di Kota Pekanbaru tahun 2017" dengan sampel yang lebih besar dan desain penelitian mix method (kuantitaif dan kualitatif).

\section{DAFTAR PUSTAKA}

A.A. Anwar Prabu Mangkunegara. 2007. Manajemen Sumber Daya Manusia Perusahaan. PT. Remaja Rosdakarya, Bandung. 
Alhadi, Esya, 2012. Pentingnya Peningkatan Soft Skill Dalam Lingkungan Kerja. Politeknik Negeri Sriwijaya: Administrasi Niaga

Dirjen Dikti Diknas. (2008). Buku Panduan Pengembangan Kurikulum Berbasis Kompetensi Pendidikan Tinggi (Sebuah Alternatif Penyusunan Kurikulum. Jakarta: Dirjen Dikti.

Dinas Kesehatan Riau. 2014. Profil Kesehatan Provinsi Riau 2014. Pekanbaru: Dinkes Riau

Depkes RI. 2006.Pedoman Manajemen Sumber Daya Manusia (Sdm) Kesehatan Dalam Penanggulangan Bencana. Jakarta: Depkes RI

Depkes RI., 2009. Sistem Kesehatan Nasional.Jakarta.

Dessler, Gary, 2007, Manajemen Personalia, Edisi Ketiga, Jakarta: Erlangga.

Elfindri dkk (2011). Soft skill untuk Pendidik. Tanpa kota: Baduose Media

Hanafi Imam. (2012). Ketrampilan Komunikasi Interpersonal Perawat Berpengaruh Peningkatan Kepuasan Pasien.

Jannah, N. 2012. Buku Asuhan Kebidanan Kehamilan . Yogyakarta : Andi

JNPK-KR. 2008. Asuhan Persalinan Normal \& Inisiasi Menyusu Dini. Jakarta . Jhpiego

Kristiana Sari. 2010. Sumber Makanan Bergizi. Yogyakarta. Nuha Medika

Kusmiyati, dkk. 2008. Perawatan Ibu Hamil. Yogyakarta; Fitramaya.

Kemenkes RI. 2007. Profil Kesehatan Indonesia 2007. Jakarta: Kemenkes RI
2007. Standar Profesi Bidan 2007. Jakarta: Kemenkes RI . 2010. Pedoman Pelayanan Antenatal Terpadu. Jakarta: Kemenkes RI . 2014. Peraturan Menteri Kesehatan Republik Indonesia Nomor 97 Tahun 2014. Jakarta: Kemenkes RI.

MA'ARIF, S. (2008). Bab 2 Tinjauan Pustaka, 6-35

Manuaba. 2008. Ilmu Kebidanan , Kandungan dan KB. Jakarta : EGC

Putra, Ichsan S., \& Pratiwi, Ariyani. 2005 Sukses Dengan Soft Skills. Bandung, Univ. Teknologi Bandung

Prawirohardjo, S. 2010. Ilmu Kebidanan. Jakarta: PT Bina Pustaka Sarwono Prawirohardjo

Prawirosentono, Suryadi. 2008. Kebijakan Kinerja Karyawan. Yogyakarta: BPFE

Rose, Colin dan Malcolm J. Nicholl. 2002. Accelerated Learning. Bandung: Nuansa.

Saifuddin, 2005. Buku Acuan Praktis Maternal dan Neonatal, Jakarta : Yayasan Bina Pustaka Sarwono Prawirohardjo.

Sulistyawati. (2011). Asuhan kebidanan pada masa kehamilan. Jakarta Salemba Medika

Syamsir Torang. 2012. Metode Riset Struktur dan Perilaku Organisasi. Bandung: Alfabeta.

Vitaly Rozhkov, Viktor Krikun, "Asterisk ZRTP Users Guide", http://zfoneproject.com/docs/asteris $\mathrm{k} / \mathrm{man} / \mathrm{html} / 2007-2008$. 